\title{
Teaching of the Japanese and Chinese Language in Extracurricular CoURSES for Children, Adolescents ANd Adults
}

\author{
Karmen FEHER MALAČIČ \\ Pionirski dom - Centre for Youth Culture, Slovenia \\ www.pionirski-dom.si \\ karmen.feher@pionirski-dom.si
}

\begin{abstract}
The presentation includes a brief history of Japanese and Chinese teaching and learning at Pionirski dom and the current trends. On the one hand, it explores the reasons why so many youngsters decide to learn Japanese or Chinese, what is their main interest and what is they want to achieve. On the other hand, it tackles the points of view of teachers of the Japanese and Chinese language towards language teaching and the issues raised while teaching. Pionirski dom is probably the only institution in Slovenia with so many young learners and teenagers enrolled in Japanese courses and with a decade of experience in the area. Much attention is, therefore, put on quality programmes and the choice of suitable teachers.
\end{abstract}

Keywords: extracurricular courses; young learners; language in use; everyday communication

\section{Povzetek}

Predstavitev vključuje kratek zgodovinski pregled poučevanja japonskega in kitajskega jezika v Pionirskem domu in trenutnih smernic. Na eni strani razišče razloge, zaradi katerih se tolikšno število najstnikov odloča za učenje japonskega ali kitajskega jezika, kaj jih pri učenju najbolj zanima in katere cilje želijo doseči. Na drugi strani pa se dotakne pogleda učiteljev na poučevanje japonskega in kitajskega jezika ter vprašanj, ki se pojavljajo v procesu poučevanja. Pionirski dom je verjetno edini zavod za obšolske dejavnosti v Sloveniji s tako velikim številom vpisanih otrok in najstnikov v tečaje japonščine in z desetletnimi izkušnjami na tem področju. Velika pozornost se tako posveča izvajanju kakovostnih programov in pravilni izbiri ustreznih učiteljev.

Ključne besede: izvenšolski tečaji/dejavnosti; mlajši učenci; uporabni jezik; vsakdanja komunikacija 


\section{General introduction}

Pionirski dom is a public institution and one of the leading institutions in the field of extracurricular activities for children and youth in Slovenia. We offer cultural-artistic programmes as well as foreign language programmes. Our experiences in foreign language teaching go as far as sixty (60) and more years in the past when Pionirski dom had a considerable influence on foreign language teaching also in the mainstream schools.

We offer courses to very young learners from the age of four (4) onwards, children, youth, students, and lately also to adults in English, German, Italian, Spanish, French, Russian, Latin, Chinese and, the last but not the least, Japanese.

We have a lot of experience in preparing students for various international exams such as the Cambridge exams in the English language, the Goethe exams in the German language, DELE exams in the Spanish language, DELF-DALF exams in the French language and CILS in the Italian language. Four years ago we also became a licensed examination centre for the Spanish international exams through the Spanish Instituto Cervantes. We started preparing our students for the international exams in English twenty-five (25) years ago and for the exams in German about twenty (20) years ago. Our aim all along has been to conduct language courses that would prepare the students to reach a certain level A1-C2 at a certain age and which could be compared to the Common European Framework of Reference for Languages (CEFR). Therefore, we tailored our programmes and included the preparation for the exams in the general courses themselves. The preparation primarily covers the introduction of the strategies of writing of such exams and the development of language skills - reading, listening, writing and speaking.

\section{Chinese and Japanese courses at Pionirski dom}

Chinese was firstly offered at Pionirski dom in 1989 and 1990 when we had a group of 10 and a group of 7 students. After that, Chinese was not taught for several years. In 2007/08 we offered a Chinese and a Japanese course and managed to form a group of students that started learning Japanese. The interest for learning Chinese was present all the time, but there were too few interested to form a whole group. However, suddenly, we noticed a growing interest in learning Japanese.

We came to the conclusion that the demand for such courses at the time must have been triggered off by the growing tourism, establishing new commerce paths and an easier access to the Chinese and Japanese culture through the internet and various media, as well as, by the growing interest of the general public to look for things beyond the European borders. 
Our main aim was to offer a new and interesting language programme, which was not common and would bring added value to the institution. At first, we thought Chinese would appeal more, however, the number of students enrolled in Japanese courses has increased over the years to surprising numbers while the number of students of Chinese has always been relatively low, just enough to keep the programme running. This being probably due to the fact that Chinese is also included in the curriculum of mainstream schools, as part of the elective programme, as well as by foreign institutions, such as the Confucious Institute. Japanese, on the other hand, is still on the way there and Pionirski dom is probably the main institution in Slovenia which at the moment offers courses of the Japanese language to all ages.

Table 1:The statistics of Chinese and Japanese learners at Pionirski dom

\begin{tabular}{lcc}
\hline Year & Chinese & Japanese \\
\hline $1989 / 90$ & 10 & - \\
$1990 / 91$ & 7 & - \\
$2007 / 08$ & - & 5 \\
$2008 / 09$ & - & 9 \\
$2009 / 10$ & - & 8 \\
$2010 / 11$ & - & 9 \\
$2011 / 12$ & 2 & 5 \\
$2012 / 13$ & 3 & 6 \\
$2013 / 14$ & 4 & 9 \\
$2014 / 15$ & - & 17 \\
$2015 / 16$ & 4 & 20 \\
$2016 / 17$ & 5 & 19 \\
$2017 / 18$ & 3 & 24 \\
\hline
\end{tabular}

The age of students varies, but the majority of students are teenagers. Officially, courses of Chinese and Japanese are offered to children and youth from the age of eight (8) onwards, although, we have also had younger students, especially in the case of Chinese. These 6-7 year-olds who start learning at Pionirski dom usually have some connection with China. Either their family lived there for some time or they travel a lot and have more frequent contacts with the Chinese culture.

So far, there have also been some adults taking individual lessons, but most of our students are either children or high school students.

From this we conclude that in comparison with other European languages taught at Pionirski dom there is a growing tendency and interest for other languages too, in particular the Asian languages - Chinese and Japanese. 


\section{Course programmes and teachers}

The beginning of the Chinese and Japanese language teaching was tough and challenging. There were three important things that had to be kept in mind:

Firstly, to find suitable teachers who would be:

- $\quad$ well-equipped with the knowledge of the language and the culture

- $\quad$ highly motivated to teach various levels, ages and mixed groups

- highly motivated to work on and develop suitable programmes (we had nothing, we started from scratch)

- dedicated

- flexible to adapt to the needs of the students

Secondly, to prepare suitable programmes:

- there were almost no materials, practically nothing useful for children in the bookshops

- no suitable course books

- teachers sometimes adapted materials they have or had used during their studies

- teachers needed to prepare their own materials and realia including, crafts, games and similar

- we had to find suitable books and materials abroad, mostly through the Internet

Thirdly, do all this in order to successfully boost the motivation of students to stay with us and proceed to higher levels - we wanted to keep the numbers of students growing.

At first, we looked for native speakers who would be teaching those courses, but soon we realised that a combination would probably work best. Our experiences with the teachers so far have proved to be fruitful both with the native speakers as well as with the excellent students and graduates. They have all put enormous efforts into preparing the materials, finding the course books and other realia that we needed. Consequently, the number of students in our courses is growing. Materials as such are constantly adapted and improved. It is an on-going project and much work will still have to be done in the future.

The teachers themselves find their work at Pionirski dom rewarding as well. All of them agree that it is a place where they get a lot of valuable experiences. As they have all pointed out there is not much opportunity for teaching Japanese and Chinese in Slovenia (most graduates end up doing other kinds of work). They also welcome the endeavours at the university studies level to include more practical teaching methodology which is obviously different to the teaching methodology of any of the European languages. Currently, they gain additional valuable practical experiences in 
teaching here at Pionirski dom. After all, the courses are paid-for and therefore the expectations are fairly high too. The teachers do not have an easy task to do. They have to find suitable ways of passing the language (which is unlike any other European language the students have been learning so far), keeping the interest of the students going, teaching them practical everyday language and various cultural aspects and at the same time to follow the students' own wishes and objectives.

\section{Students' great expectations}

To be able to offer the best in our courses we need to consider the wishes of our students and the current tendencies. By conducting a survey among the students we particularly wanted to learn why they have decided to enrol in the course, what previous contacts with the Chinese or Japanese language they have already had and what they want to achieve.

The following are the results of the latest survey.

Question 1: WHY?

- I watch anime and therefore I am interested in the language and the culture

- I read mangas and therefore I am interested in the language and the culture

- I practice judo and I became interested in the Japanese culture and language

- I wanted to learn a non-European language which has a different way of writing

- I wanted to try something new

- I am interested in the Japanese culture and language

- I find Japanese a beautiful language " that sounds cute«

- I learned about Japan and Japanese through media, film, the internet and I want to know more

- I watch films, listen to the Japanese music

- I am interested in the cultural differences and similarities

- I am interested in the Japanese literature

- There are a lot of good schools of design in Japan

Question 2: WHAT previous contacts have you already had?

- none

- anime

- mangas

- the Internet, media, films, art

- judo 
- I visited Japan

- I have friends that already know some Japanese or have visited Japan

- my grandfather worked on a ship trading with Japan and my grandmother has some articles at home (a vase and other) that come from Japan

- food

- Wikipedia

Question 3: MY AIMS - What do you want to learn in the course?

- everyday language

- spoken language

- practical phrases for communication

- enough Japanese to be able to communicate with tourists here or when in Japan

- communication on a higher level

- level B2 (CEFR)/N3 (JLPT)

- I want to become fluent enough to be able to watch anime without the subtitles

- to get to know some basic language

- $\quad$ enough to understand word games

- to get to know the culture, the nature of Japan and the country

- to learn about grammar and history

- I want to study Japanese at the university and I want to prepare beforehand

The majority of the students is interested in taking the international exam in the Japanese language JLPT eventually.

\section{Conclusion}

To conclude, in comparison to other European languages taught at Pionirski dom, there is a growing tendency and interest for other languages in particular Asian languages such as Chinese and Japanese. Therefore, we will continue our work in this field by adapting and developing our programmes and we will support the spreading of the Chinese and Japanese language learning by boosting the (already high) motivation of our students to continue learning these two languages also in the future. Motivation, we find, is the main key to success.

Karmen Feher Malačič is the Head of the Department of Foreign Languages and Cultures at Pionirski dom Centre for Youth Culture and a full-time teacher of English. She holds B.A. in the English language and literature and international certificates in English, Italian, French, Spanish and German. She is also a Cambridge speaking examiner and a YL Team Leader with the British Council Slovenia. She is a former editor of IN-latefl Slovenia Magazine. 